\title{
A case report of a boy suffering from type 1 diabetes mellitus and familial Mediterranean fever
}

\author{
Maria Francesca Gicchino ${ }^{*}$ (D), Dario lafusco, Angela Zanfardino, Emanuele Miraglia del Giudice and \\ Alma Nunzia Olivieri
}

\begin{abstract}
Background: Type 1 diabetes mellitus could be associated with other autoimmune diseases, such as autoimmune thyroid disease, celiac disease, but the association with Familial Mediterranean Fever is rare, we describe a case of a boy with type 1 Diabetes Mellitus associated with Familial Mediterranean Fever (FMF).

Case presentation: A 13 year old boy already suffering from Diabetes Mellitus type 1 since the age of 4 years, came to our attention because of periodic fever associated with abdominal pain, chest pain and arthralgia. The fever appeared every $15-30$ days with peaks that reached $40^{\circ} \mathrm{C}$ and lasted $24-48 \mathrm{~h}$. Laboratory investigation, were normal between febrile episodes, but during the attacks revealed an increase in inflammatory markers. Suspecting Familial Mediterranean Fever molecular analysis of MEFV gene, was performed. The genetic analysis showed homozygous E148Q mutation. So Familial Mediterranean Fever was diagnosed and colchicine treatment was started with good response.

Conclusion: Familial Mediterranean Fever could be associated with other autoimmune diseases such as Ankylosing Spondylitis, Rheumatoid Arthritis, Polyarteritis Nodosa, Behcet disease, Systemic Lupus, Henoch-Schönlein Purpura, and Hashimoto's Thyroiditis. Association of type 1 Diabetes Mellitus and Familial Mediterranean Fever has been newly reported in the medical literature, this is the third association of these two diseases described in the medical literature so far.
\end{abstract}

Keywords: Recurrent fever, Abdominal pain, Arthritis, Diabetes mellitus, Colchicine, Anti interleukin 1 drugs

\section{Background}

Familial Mediterranean fever (FMF) is a monogenic autoinflammatory disease with autosomal recessive inheritance [1]. The main clinical findings of FMF are recurrent and self-limited fever attacks lasting between 12 to $72 \mathrm{~h}$. Severe abdominal, articular and/or chest pain, due to inflammation of the peritoneum, synovia or pleura usually accompany fever [2]. The most important

* Correspondence: francesca.gicchino@gmail.com

Department of Woman, Child and General and Specialized Surgery,

University of the Study of Campania "Luigi Vanvitelli", Naples, Italy factor determining the prognosis of FMF is the development of amyloidosis, which could lead to renal failure [3]. FMF is the most common hereditary recurrent fever syndrome [1]. Approximately 150,000 people worldwide are estimated to have this condition. FMF has been report all around the world, but its prevalence is very high among certain ethnic groups such as Jewish, Turkish, Armenian and Arabs, reaching figures as high as $1 / 500$ individuals [4].FMF result from a mutation of the Mediterranean fever (MEFV) gene, located on chromosome 16 [5] and is inherited in an autosomal recessive manner. Nearly $30 \%$ of documented FMF patients carry only

(c) The Author(s). 2021 Open Access This article is licensed under a Creative Commons Attribution 4.0 International License, which permits use, sharing, adaptation, distribution and reproduction in any medium or format, as long as you give appropriate credit to the original author(s) and the source, provide a link to the Creative Commons licence, and indicate if changes were made. The images or other third party material in this article are included in the article's Creative Commons licence, unless indicated otherwise in a credit line to the material. If material is not included in the article's Creative Commons licence and your intended use is not permitted by statutory regulation or exceeds the permitted use, you will need to obtain permission directly from the copyright holder. To view a copy of this licence, visit http://creativecommons.org/licenses/by/4.0/ The Creative Commons Public Domain Dedication waiver (http://creativecommons.org/publicdomain/zero/1.0/) applies to the data made available in this article, unless otherwise stated in a credit line to the data. 
one mutation, and up to $20 \%$ of patients do not have detectable mutations [6, 7]. More than $50 \mathrm{FMF}$-associated mutations in MEFV have been reported [8]. The most frequent are: M694V, V726A, M694I, and M680I located at exon 10 and E148Q located at exon 2 [1]. The MEFV gene encodes the protein pyrin, that has an important role in the inflammatory response by regulating caspase1 activation and processing mature IL-1 $\beta$ [9]. The diagnosis of FMF relies mainly on clinical findings, and molecular analysis of the $M E F V$ gene provides genetic confirmation [10]. There are different sets criteria for FMF diagnosis. The first set criteria was created for adults by a group of experts [11]. In 2009 Yalcikaya et al. validated a set criteria for paediatric patients [12]. Recently, the Eurofever group proposed a new set criteria for autoinflammatory recurrent fevers (these sets criteria are compared in Table 1) [13] . Colchicine is the standard treatment for FMF. However, it could be ineffective or associated with side effects in 5 to $10 \%$ of patients [13]. Interleukin-1(IL-1) inhibition could be useful in colchicine resistant FMF patients [14-16] . Canakinumab is the only biologic agent approved by the U.S. FDA for the treatment of FMF [17].

FMF could be associated with other autoimmune diseases such as ankylosing spondylitis, rheumatoid arthritis, polyarteritis nodosa, Behcet, and Systemic Lupus, and Hashimoto's thyroiditis $[18,19]$. Association of type 1 diabetes mellitus (T1D) and FMF has been newly reported in the medical literature $[20,21]$. We report a case of a boy suffering from T1D, who developed FMF. This is the third association of these two diseases described in the medical literature.

\section{Case report}

The patient was in follow up in the Paediatric Diabetological Center of our Department because he developed
T1D at the age of 4 . At the age of 13 he was referred to the Paediatric Rheumatological Centre of our Department because of episodes of recurrent fever since the age of 6 . Fever attacks, with temperature ranging between 39 to $40^{\circ} \mathrm{C}$, lasted 24 to $72 \mathrm{~h}$ and occurred every 21-30 days. These episodes where associated with arthralgia, abdomen, and chest pain.

Over the years because of fever and abdominal pain, the patient usually referred to Emergency, where he underwent to abdomen ultrasounds in order to exclude acute appendicitis. Blood tests performed during fever attacks showed increase in inflammatory parameters, erythrocyte sedimentation rate (ERS) and C-reactive protein (CRP).

Fever attacks were treated with antipyretic drugs and in some occasion with antibiotic. Between attacks patient was well and blood tests were normal. The patient came to our attention during a febrile attack. Physical examination revealed: fever (body temperature up to $40{ }^{\circ} \mathrm{C}$ ), abdominal and chest pain, arthritis of the right ankle. Blood tests revealed an increase in white cells $\left(17.000 / \mathrm{mm}^{3}\right.$, normal value $\left.<10.000 / \mathrm{mm}^{3}\right)$, ERS $(60$ $\mathrm{mm} / \mathrm{h}$ ), CRP $(3.7 \mathrm{mg} / \mathrm{dl})$ serum amyloid A (SAA,200 $\mathrm{mg} / \mathrm{dL}$ ). Blood tests were unremarkable for: viral serology, liver and kidney function, serum immunoglobulins,coeliac screening, thyroid hormone, antinuclear antibodies, extractable nuclear antigens, anti neutrophil Cytoplasmic antibodies, rheumatoid factor, anti-double stranded DNA, serum antistreptolysin O titre and complement levels. Throat swab was negative and so were the urinalysis, and the abdomen ultrasound. Chest ultrasound showed pleural effusion. Given his personal history, clinical and laboratory findings FMF was suspected, so colchicine therapy ( $1 \mathrm{mg} /$ day) was prescribed and genetic investigation was performed. The molecular analysis of MEFV gene, showed homozygous E148Q

Table 1 Comparison of Tel-Hashomer, Yalcinkaya Ozen and Eurofer/Printo set criteria (modified from references 11,12,13). TekHashomer is a writing error, it should be changed in Tel-Hashomer

\begin{tabular}{|c|c|c|c|}
\hline Tel Hashomer Criteria & Yalcinkaya Ozen criteria & $\begin{array}{l}\text { Eurofever/PRINTO clinical + genetic } \\
\text { criteria }\end{array}$ & $\begin{array}{l}\text { Eurofever/PRINTO } \\
\text { clinical only criteria }\end{array}$ \\
\hline $\begin{array}{l}\text { Major Criteria } \\
\text { 1.Recurrent febrile episodes with serosi- tis } \\
\text { (peritonitis, synovitis or pleuritis) } \\
\text { 2- Amyloidosis of AA type without a } \\
\text { predisposing disease } \\
\text { 3- Favorable response to regular colchi- } \\
\text { cine treatment } \\
\text { Minor Criteria } \\
\text { 1- episodes } \\
\text { 2- FMF in a first-degree relative 3- } \\
\text { Erysipelas-like erythema }\end{array}$ & $\begin{array}{l}\text { 1- Fever (Axillary temperature of }> \\
38^{\circ} \mathrm{C}, 672 \mathrm{~h} \text { of duration, }>3 \\
\text { attacks) } \\
\text { 2- Abdominal pain ( } 672 \mathrm{~h} \text { of } \\
\text { duration, }>3 \text { attacks) } \\
3 \text { - Chest pain ( } 672 \mathrm{~h} \text { of duration, } \\
>3 \text { attacks) } \\
4 \text { - Arthritis ( } 672 \mathrm{~h} \text { of duration, }>3 \\
\text { attacks, oligoarthritis) } \\
5 \text { - Family history of FMF }\end{array}$ & $\begin{array}{l}\text { Presence of confirmatory MEFV genotype } \\
\text { and at least one among the following } \\
\text { 1-Duration of episodes } 1-3 \text { days } \\
\text { 2-Arthritis } \\
\text { 3- Chest pain } \\
\text { 4- Abdominal pain } \\
\text { OR } \\
\text { Presence of not confirmatory MEFV } \\
\text { genotype and at least two among the } \\
\text { following } \\
\text { 1-Duration of episodes } 1-3 \text { days } \\
\text { 2-Arthritis } \\
\text { 3-Chest pain } \\
\text { 4- Abdominal pain }\end{array}$ & $\begin{array}{l}\text { Presence of 1-Eastern } \\
\text { Mediterranean } \\
\text { ethnicity } \\
\text { 2-Duration of episodes } \\
\text { 1-3 days } \\
\text { 3- Arthritis } \\
\text { 4- Chest pain } \\
\text { 5- Abdominal pain } \\
\text { Absence of } \\
\text { 1-Aphthous stomatitis } \\
\text { 2- Urticarial rash } \\
\text { 3- Maculopapular rash } \\
\text { 4- Painful lymph } \\
\text { nodes }\end{array}$ \\
\hline 2 major criteria or 1 major +2 minor criteria & $>2$ criteria & $>6$ criteria & \\
\hline
\end{tabular}


mutation. Colchicine determined the immediate disappearance of the symptoms and normalization of inflammatory parameters. Colchicine was well tolerated.

After 1 year a renal biopsy was performed because of onset of persistent microalbuminuria. On biopsy Congo red staining was negative, so amyloidosis was excluded, but a slight and irregular thickening of the lamina densa of some glomerular capillaries was detected, so diabetic nephropathy was diagnosed and Ramipril treatment (2, $5 \mathrm{mg} /$ day) was prescribed. Regarding FMF, after 18 months without symptoms, the patient presented again fever and abdominal pain, associated with an increase in inflammatory parameters, so colchicine was increased to $1.5 \mathrm{mg} /$ day. On his recent follow up visit, at 17 years of age, the patient was in good general conditions. Daily insulin requirement was $0,8 \mathrm{U} / \mathrm{kg} /$ day. Patient did not refer fever or abdominal pain, and urynalysis did not reveal microalbuminuria. As he did not refer any side effects, both colchicine $(1,5 \mathrm{mg} /$ day $)$ and ramipril $(2,5 \mathrm{mg} /$ day $)$ were confirmed.

\section{Discussion and conclusion}

FMF is an autoinflammatory disease with autosomal recessive inheritance. Our patient presented homozygous E148Q mutation. E148Q is the most frequent variant among carriers, its pathogenic role is uncertain [22]. In a recent analysis Topaloglu et al. demonstrated that patients homozygous for E148Q displayed typical FMF phenotype and half of these patients had moderate/severe disease before colchicine treatment [22].

Aydin et al. demonstrated that E148Q mutation is associated with a milder disease course, despite patients may have similar clinical findings and well response to colchicine therapy, when compared to patients with other mutations [23]. In our case, the patient presented recurrent fever episodes associated to abdominal, chest pain, and arthralgia and presented a good response to colchicine treatment.

It has been reported that E148Q mutation could induce a nonamyloidosis renal involvement. In particular Eroglu et al. described a case of mesangial proliferative glomerulonephritis in a woman affected by FMF with an heterozygous E148Q mutation [24]. Ardalan et al. reported a case of an acute glomerulonephritis with proteinuria in a patient affected from FMF with an heterozygous E148Q mutation [25]. Our patient presented persistent microalbuminuria 1 year later FMF diagnosis, so a renal biopsy was performed that revealed slight and irregular thickening of the lamina densa of some glomerular capillaries. This histopathological finding was compatible with diabetic nephropathy, so treatment with Ramipril was started [26].
Pyrin, the protein product of MEFV, is a 781aminoacid protein expressed in serosal and synovial fibroblasts, granulocytes, and cytokine-activated monocytes.

The role of pyrin in IL-1 activation is controversial [8], Campbell et al. supposed that pyrin suppresses the activation of pro-caspase-1, by competing for ASC (apoptosis-associated speck-like protein containing a caspase recruitment domain), and therefore pyrin interferes with NALP3 inflammasome activation [8]. Chae et al demonstrated that Pyrin containing FMF-associated mutations has less of an inhibitory effect on the inflammasome, leading to upregulated synthesis of IL-1 $[9]$.

T1D is a T-cell-mediated autoimmune disease characterized by the destruction of pancreatic beta cells in genetically predisposed individuals [27].

As in other autoimmune conditions, both innate and adaptive immunity play a role in disease pathogenesis $[28,29]$.

Kumar et al. demonstrated that T-helper type 17 (Th17) cells, have a pivotal role in T1D pathogenesis [30]. Proinflammatory cytokine, in particular interleukin 1 (IL-1) and 6 (IL-6), are involved in differentiation of $\mathrm{T}$-cells in Th17 [30]. It has been demonstrated that TNF $\alpha$, IL- 1 and IL- 6 are increased in diabetic subjects compared to control subjects at onset of clinical disease. These cytokine inducing differentiation of T-cells in Th17 are involved in T1D pathogenesis [31, 32].

Recent studies have demonstrated NLRP3 inflammosome and IL-1 iper-production could play an important role in the development of T1D in mice [33]. The coexistence of FMF and type T1D is a rare finding. In 2006 Atabek et al. described a case of a 9 years old girl affected from T1D who developed FMF 11 months later diabetes onset [20]. In 2009 Baş et al. reported a second patient with type T1D associated with FMF who also had autoimmune thyroid disease (ATD), celiac disease (CD) [21].

According to the recent progress in the understanding of T1D pathogenesis, in particular regarding the increase in serum levels of IL1 and IL6 at the onset of diabetes, we can suppose that the higher production of IL1 in FMF could be involved in development of T1D. Further studies or case series are needed to demonstrate this possible association.

Here we report the third association of FMF and T1D. FMF should be kept in mind in the differential diagnosis of disorders associated with T1D in the presence of recurrent and limited attacks of fever, associated with abdominal or chest pain or arthritis. The emerging role of the inflammatory cytokine (TNF $\alpha$, IL-1 and IL-6)in the development of T1D adds a further dimension to our understanding of the multifactorial nature of the immunopathology that leads to the development of T1D but also opens a new area of research for potential therapy. 


\section{Abbreviations}

FMF: Familial Mediterranean Fever; IL-1: Interleukine 1; IL-6: Interleukine 6; T1D: Type 1 diabetes mellitus; ERS: Erythrocyte sedimentation rate; CRP: Creactive protein; SAA: Serum amyloid A; ASC: Apoptosis-associated speck-like protein containing a caspase recruitment domain; TNFa: Tumor necrosis factor alfa; Th-17: T-helper type 17; ATD: Autoimmune thyroid disease; CD: Celiac disease

\section{Acknowledgements}

All Authors are grateful to Prof. Maria Rosaria Taddeo for the English revision of the manuscript.

\section{Authors' contributions}

MFG: involvement in medical diagnosis and follow up of the patient; first writers of the manuscript (they contributed equally to this work). AZ, DI, ANO: involvement in diagnosis and management of the patient. ANO, EM: supervision of the medical procedures and of the process of the manuscript. All authors read and approved the final manuscript.

\section{Funding}

There is no institutional, financial or material support for publishing the manuscript.

\section{Availability of data and materials}

Not applicable.

\section{Declarations}

\section{Ethics approval and consent to participate}

Not applicable.

\section{Consent for publication}

Written informed consent was obtained from the patient's parents for publication of this case report.

\section{Competing interests}

The authors declare no potential competing interests with respect to the research, authorship, and/or publication of this article.

Received: 24 November 2020 Accepted: 17 May 2021

Published online: 02 June 2021

\section{References}

1. Sari I, Birlik M, Kasifoglu T. Familial Mediterranean fever: an updated review. Eur J Rheumatol. 2014;1(1):21-3. https://doi.org/10.5152/eurjrheum.2014.006.

2. Ozen S, Bilginer Y. A clinical guide to autoinflammatory diseases: familial Mediterranean fever and next-of-kin. Nat Rev Rheumatol. 2014;10(3):135-47. https://doi.org/10.1038/nrrheum.2013.174.

3. Nursal AF, Tekcan A, Kaya SU, Turkmen E, Yigit S. Mutational Spectrum of the MEFV Gene in AA Amyloidosis Associated With Familia Mediterranean Fever. IJKD. 2016;10:107-12.

4. Ozen S. Update on the epidemiology and disease outcome of Familia Mediterranean fever. Best Pract Res Clin Rheumatol. 2018;32:254e260.

5. International FMF Consortium. Ancient missense mutations in a new member of the RoRet gene family are likely to cause familial Mediterranean fever. Cell. 1997;90:797-807.

6. Ozen S, Batu ED, Demir S. Familial Mediterranean fever: recent developments in pathogenesis and new recommendations for management. Front Immunol. 2017;8:253. https://doi.org/10.3389/fimmu.201 7.00253 eCollection.

7. Ben-Zvi I, Herskovizh C, Kukuy O, Kassel Y, Grossman C, Livneh A. Familial Mediterranean fever without MEFV mutations: a case-control study. Orphanet J Rare Dis. 2015;10:34

8. Campbell L, Raheem I, Malemud CJ, Askari AD. The relationship between NALP3 and autoinflammatory syndromes. Int J Mol Sci. 2016;17(5):725. https://doi.org/10.3390/ijms17050725.

9. Chae JJ, Cho YH, Lee GS, Cheng J, Liu PP, Feigenbaum L, et al. Gain of function pyrin mutations induce NLRP3 protein -independent interleukin-1 beta activation and severe autoinflammation in mice. Immunity. 2011:34(5): 755-68. https://doi.org/10.1016/j.immuni.2011.02.020.
10. Sönmez HE, Batu ED, Özen S. Familial Mediterranean fever: current perspectives. J Inflamm Res. 2016;9:13-20. https://doi.org/10.2147/JR. S91352.

11. Livneh A, Langevitz P, Zemer D, Zaks N, Kees S, Lidar T, et al. Criteria for the diagnosis of familial Mediterranean fever. Arthritis Rheum. 1997;40(10):187985. https://doi.org/10.1002/art.1780401023.

12. Yalcinkaya F, Ozen S, Ozcakar ZB, et al. A new set of criteria for the diagnosis of familial Mediterranean fever in childhood. Rheumatology. 2009; 48(4):395-8. https://doi.org/10.1093/rheumatology/ken509.

13. Ozen S, Demirkaya E, Erer B, Livneh A, Ben-Chetrit E, Giancane G, et al. EULAR recommendations for the management of familial Mediterranean fever. Ann Rheum Dis. 2016;75(4):644-51. https://doi.org/10.1136/a nnrheumdis-2015-208690.

14. Gül A, Ozdogan H, Erer B, et a (2015) Efficacy and safety of canakinumab in adolescents and adults with colchicine-resistant familial Mediterranean fever. Arthritis Res Ther 17:243, 1, DOI: https://doi.org/10.1186/s13075-0150765-4.

15. Ozen S, Bilginer Y, Aktay Ayaz N, Calguneri M. Anti-interleukin 1 treatment for patients with familial Mediterranean fever resistant to colchicine. J Rheumatol. 2011;38(3):516-8. https://doi.org/10.3899/jrheum.100718.

16. Ozen S, Kone-Paut I, Gül A. Colchicine resistance and intolerance in familial mediterranean fever: definition, causes, and alternative treatments. Semin Arthritis Rheum. 2017;47(1):115-20. https://doi.org/10.1016/j.semarthrit.2017. 03.006 .

17. Ilaris (canakinumab) Prescribing Information. Novartis Pharmaceuticals Corporation. 2016.

18. Ergul AB, Dursun I, Torun YA. Hashimoto's thyroiditis in a child with familial mediterranean fever: a case report. Iran J Pediatr. 2013;23:489e90.

19. Erten S, Taskaldiran I, Yakut ZI. Are systemic lupus erythematosus patients carrying MEFV gene less prone to renal involvement? Report of three cases and review of the literature. Ren Fail. 2013;35:1013e6.

20. Atabek ME, Pirgon O, Sert A, Arslan U. Familial Mediterranean fever associated with type 1 diabetes. Endocrinol. 2006;16:133e5.

21. Bas F, Kabatas-Eryılmaz S, Günöz H, Darendeliler F, Küçükemre B, Bundak R, et al. Type 1 diabetes mellitus associated with autoimmune thyroid disease, celiac disease and familial Mediterranean fever: case report. Turk J Pediatr. 2009;51:183e6.

22. Topaloglu R, Batu ED, Yıldız C, Korkmaz E, Özen S, Beşbaş N, et al. Familial Mediterranean fever patients homozygous for E148Q variant may have milder disease. Int J Rheum Dis. 2018;21(10):1857-62. https://doi.org/1 $0.1111 / 1756-185 X .12929$

23. Aydın F, Çakar N, Özçakar ZB, Uncu N, Başaran O, Özdel S. Clinical features and disease severity of Turkish FMF children carrying E148Q mutation. J Clin Lab Anal. 2019;33(4):e22852. https://doi.org/10.1002/jcla.22852.

24. Eroglu E, Kocyigit I, Ates O, Unal A, Sipahioglu MH, Akgun H, et al. Mesangial proliferative glomerulonephritis in familial Mediterranean fever patient with E148Q mutation: the first case report. Int Urol Nephrol. 2013; 45(2):591-4. https://doi.org/10.1007/s11255-012-0124-1.

25. Ardalan M, Nasri $\mathrm{H}$. Massive proteinuria and acute glomerulonephritis picture in a patient with Familial Mediterranean fever and E148Q mutation. Iran J Kidney Dis. 2014:8(6):486-8.

26. Chandragiri S, Raju SB, Mandarapu SB, Goli R, Nimmagadda S, Uppin M. A Clinicopathological study of 267 patients with diabetic kidney disease based on the Renal Pathology Society - 2010 classification system. Indian J Nephrol. 2020;30(2):104-9.

27. DiMeglio LA, Evans-Molina C, Oram RA. Type 1 diabetes. Lancet. 2018;391: 2449-62. https://doi.org/10.1016/S0140-6736(18)31320-5.

28. Diplomatico M, Gicchino MF, Ametrano O, Marzuillo P, Olivieri AN. A case of urticarial vasculitis in a female patient with lupus: mycoplasma pneumoniae infection or lupus reactivation? Rheumatol Int. 2017:37(5):837-40. https:// doi.org/10.1007/s00296-016-3626-9

29. Olivieri AN, lafusco D, Mellos A, Zanfardino A, Mauro A, Granato C, et al. Refractory rheumatoid factor positive polyarthritis in a female adolescent already suffering from type 1 diabetes mellitus and Hashimoto's thyroiditis successfully treated with etanercept. Ital J Pediatr. 2013;39:64.

30. Kumar P, Subramaniyam G. Molecular underpinnings of Th17 immuneregulation and their implications in autoimmune diabetes. Cytokine. 2015; 71(2):366-76. https://doi.org/10.1016/..cyto.2014.10.010.

31. Dogan Y, Akarsu S, Ustundag B, Yilmaz E, Gurgoze MK. Serum IL-1beta, IL-2, and IL-6 in insulin-dependent diabetic children. Mediat Inflamm. 2006: 2006(1):59206. https://doi.org/10.1155/MI/2006/59206. 
32. Bradshaw EM, Raddassi K, Elyaman W, Orban T, Gottlieb PA, Kent SC, et al. Monocytes from patients with type 1 diabetes spontaneously secrete proinflammatory cytokines inducing Th17 cells. J Immunol. 2009;183(7): 4432-9. https://doi.org/10.4049/jimmunol.0900576.

33. Hu C, Ding H, Li Y, Pearson JA, Zhang X, Flavell RA, et al. NLRP3 deficiency protects from type 1 diabetes through the regulation of chemotaxis into the pancreatic islets. Proc Natl Acad Sci U S A. 2015;112(36):11318-23. https://doi.org/10.1073/pnas.1513509112.

\section{Publisher's Note}

Springer Nature remains neutral with regard to jurisdictional claims in published maps and institutional affiliations.

Ready to submit your research? Choose BMC and benefit from:

- fast, convenient online submission

- thorough peer review by experienced researchers in your field

- rapid publication on acceptance

- support for research data, including large and complex data types

- gold Open Access which fosters wider collaboration and increased citations

- maximum visibility for your research: over $100 \mathrm{M}$ website views per year

At $\mathrm{BMC}$, research is always in progress.

Learn more biomedcentral.com/submissions 